\title{
EKONOMI LUMBUNG DAN KONSTRUKSI KEBERDAYAAN PETANI MUSLIM MADIUN
}

\author{
Sirajul Arifin \\ UIN Sunan Ampel Surabaya \\ sirajul.arifin@uinsby.ac.id \\ Muhammad Andik Izzuddin \\ UIN Sunan Ampel Surabaya \\ andik@uinsby.ac.id
}

\begin{abstract}
:
Muslim farmers of Luworo Madiun often suffer from the hegemony of ijon (debt bondage) system. The system which exploits and weakens the farmers can no longer be tolerated, but should be responded through the construction of lumbung (barn; place for rice storage). The lumbung which is constructed next to mosque can become an important asset for creating food security and solving the economic problems of the farmers. However, lumbung asset will not survive or develop if not supported by other assets. The mosque, market, agricultural area, and society itself all are important assets developed by the farmers of Luworo to strengthen the survival and development of lumbung asset. The lumbung then has power not only to build food security but also to strengthen the economic capacity of society. This economic power is developed through the construction of lumbung which gives equal rights to all members, in contrast to the unjust and exploitative ijon system.
\end{abstract}

Keywords: Muslim Farmers; Ijon System; Mosque Lumbung; Market

\section{Abstrak}

Masyarakatpetani Muslim Luworo Madiun adalab masyarakatyang kerapterhegemoni oleh sistem ijon. Sistem ijon yang membelit dan membuat petani Luworo tidak berdaya tentu tidak dapat dibiarkan melainkan harus direspons melalui konstruksi lumbung. Lumbung masjid sebagai asset ekonomi dibangun untuk menciptakan ketahanan pangan dan sekaligus mengatasi problem ekonomi petani. Namun asset lumbung tidak mungkin dapat hidup bahkan berkembang jika tidak didukung oleh asset-asset lainnya. Keberadaan asset masjid, pasar, area pertanian, dan masyarakat adalah asset-asset yang dikembangkan oleh masyarakat petani Luworo untuk mengkostruk survivalitas dan pengembangan asset lumbung. Keberadaan lumbung memiliki kekuatan bukan sekadar kekuatan membangun ketabanan pangan tetapi juga kekuatan ekonomi masyarakat. Kekuatan ekonomi masyarakat terbentuk melalui kebijakan lumbung yang memberikan hak yang sama secara adil kepada semua anggota dan bukan kezaliman seperti yang terkonstruk dalam sistem ekonomi ijon.

Kata kunci: Petani Muslim, Ijon, Lumbung Masjid, Pasar

Permalink/DOI: http://dx.doi.org/10.18326/infsl3.v10i1.187-212 


\section{Pendahuluan}

Masyarakat petani Muslim Luworo Madiun banyak dikenal dengan masyarakat yang sarat dengan masalah. Masalah muncul silih berganti. Salah satu masalah yang kerap menyandera petani adalah masalah ijonisasi (Wawancara, 31 September 2015; FGD, 10 Oktober 2015). Petani tersandera dan terpenjara karena ketidakberdayaannya secara ekonomi. Keadaan mereka yang tak berdaya menjadi peluang masuknya tengkulak dan menjadi lahan aksi eksploitatif-monopolistik melalui praktik ijon. Ijon merupakan bentuk perkreditan informal yang berkembang di daerah pedesaan (Wijaya, 1991).

Logika kredit adalah logika yang merefleksikan kehadiran bunga. Suku bunga bisa tinggi dan bisa rendah. Tinggi rendahnya suku bunga sangat bergantung pada siapa yang memegang polesi. Jika tengkulak yang memegang kebijakan dan mengatur besaran bunga, maka jelas bahwa komunitas petani akan tersandera dan tereksploitasi terutama ketika bunga kredit terlampau tinggi (Asmara, Hanani, dan Suryaningtyas, 2011: 129-130). Tingkat suku bunga kredit, jika diperhitungkan pada waktu pengembalian, sangat tinggi dan berkisar antara 10-40\%, sehingga menimbulkan masalah ekonomi (Wawancara, 30 September 2015; FGD, 10 Oktober 2015).

Beberapa persoalan yang menjadikan praktik ijon ini tetap survive tidak terlepas dari problem ekonomi komunitas petani. Salah satu problemnya adalah adanya serial kebutuhan, mulai kebutuhan biaya tanam sampai dengan kebutuhan biaya panen. Rentang waktu tersebut memerlukan biaya banyak. Selain itu, petani juga dihadapkan pada pemenuhan kebutuhan sehari-hari. Ketika kebutuhan mereka mendesak, maka jalan yang ditempuh untuk memenuhi kebutuhannya adalah mengajukan pembiayaan dengan sistem ijon (Wawancara, 3 Oktober 2015; FGD, 17 Oktober 2015). Jalur ini ditempuh saat para petani menemui jalan buntu karena akses mereka ke lembaga keuangan, seperti bank, tertutup oleh persyaratan administratif-normatif yang mengharuskan jaminan dan syarat administratif lainnya. Persyaratan yang demikian tentu sulit untuk dipenuhi karena selain mereka tidak memiliki agunan juga mereka terkendala oleh pendidikannya yang rendah. 
Di sinilah masyarakat petani Muslim Luworo harus kreatif dan mampu berdikari sehingga dapat lepas dari jeratan sistem ijon. Menjadi petani memiliki kebanggaan tersendiri, karena sektor pertanian adalah soko guru kedaulatan ekonomi di bidang pangan. Peluang ekonomi sebenarnya terbuka lebar jika masyarakat petani mampu melihat potensi yang ada di sekitarnya. Potensi mereka sebenarnya ada, dan karenanya merupakan asset yang bisa dikembangkan. Dalam konteks masyarakat petani Muslim Luworo, asset yang bisa dikembangkan adalah lumbung masjid yang besar dan bisa menampung sekian banyak tonase padi, masjid yang menjadi tempat bertemunya para petani, lahan pertanian di sekitar masjid yang juga sangat luas, areal persawahan yang subur, masyarakat petani desa yang guyub dan kompak, dan berbagai asset lainnya (Kepala Desa Luworo, 2015; Wawancara, 18 September 2015; Wawancara, 22 September 2015; Wawancara, 3 Oktober 2015; FGD, 17 Oktober 2015).

Varian asset masyarakat di atas merupakan asset-asset yang potensial untuk dikembangkan. Karenanya, program lumbung hikmah yang digagas oleh komunitas petani Muslim Peron yang dipusatkan di Masjid Ngudi Luhur Desa Luworo Kecamatan Pilangkenceng Kabupaten Madiun adalah sebuah program untuk memperkuat ekonomi masyarakat petani setempat, sehingga mampu memproteksi masuknya tengkulak yang menghegemoni dan mengeksploitasi ekonomi komunitas petani. Program ini memang telah digagas, namun program tinggal program (Wawancara, 31 September 2015; FGD, 17 Oktober 2015). Program penguatan ekonomi ini belum bisa berjalan karena faktor modal yang tampak masih kesulitan dan belum dapat dipenuhi.

Keterbatasan permodalan--selain keterbatasan lainnya-kemudian menjadi kendala, dan karenanya, perlu ada solusi. Solusi yang dapat memberikan jalan keluar merupakan suatu keniscayaan dan sekaligus sebagai respons terhadap persoalan, yaitu; pertama, bagaimana masyarakat petani Muslim Desa Luworo Pilangkenceng Madiun membangun lumbung di tengah-tengah perekonomian berbasis ijon, dan kedua, bagaimana lumbung dikembangkan untuk penguatan ekonomi masyarakat petani Muslim Desa Luworo Pilangkenceng Madiun. 
Bertolak dari dua masalah pokok di atas, maka artikel ini mencoba untuk meneliti, menelaah dan memahami secara mendalam baik tentang masyarakat petani Muslim Desa Luworo ketika membangun lumbung masjid di tengah-tengah perekonomian berbasis ijon maupun tentang program lumbung yang dirancang untuk dikembangkan dalam upaya penguatan ekonomi masyarakat petani tersebut.

\section{Kajian Teori}

\section{Pemberdayaan Masyarakat}

Pembangunan masyarakat selain mecakup elemen sosial, ekonomi, dan politik juga memperhatikan elemen pengembangan masyarakat yang meliputi pengembangan budaya lingkungan, dan pengembangan spiritual (Ife, Tesoriero, 2008: 447-448). Elemen yang demikian tentu tidak hanya menyentuh dan berhenti pada titik penbangunan tetapi juga menjangku pada titik pengembangannya dalam berbagai basis baik basis sumberdaya lokal, basis modal sosial, basis kebudayaan, basis kearifan lokal, maupun basis modal spiritual (Mardikanto, 2014: 25).

Pembangunan masyarakat yang dikenal dalam banyak literatur mencakup tiga model, yaitu; economic growth, basic needs, dan people centered. Dari ketiga model pembangunan ini, model yang ketiga menjadi pilihan dalam pemberdayaan masyarakat dewasa ini. People centered merupakan model pembangunan yang merefleksikan nilainilai sosial yang bersifat participatory, empowering, dan sustainable. Model ini lebih luas dari sekadar memenuhi kebutuhan dasar atau menyediakan mekanisme untuk mencegah proses pemiskinan lebih lanjut (Mardikanto, 2014: 13), sehingga pembangunan berbasis masyarakat dengan menggunakan strategi pemberdayaan akan lebih tepat dalam mengubah kondisi masyarakat.

Pemberdayaan berasal dari kata empowerment yang bermakna pemberian kekuasaan karena power bukan hanya daya tetapi juga kekuasaan, sehingga kata daya tidak saja bermakna mampu tetapi juga mempunyai kuasa (Wrihatnolo, Dwidjowijoto, 2007: 1). Pemberdayaan, karenanya, merupakan upaya memberikan 
daya empowerment kepada masyarakat (Mas'oed, 1990: 27). Keberdayaan masyarakat oleh Sumodiningrat diartikan sebagai kemampuan individu yang melekat dengan masyarakat dalam membangun keberdayaan masyarakat (Sumodinigrat, 1999). Karena itu, pemberdayaan dapat disamakan dengan perolehan kekuatan dan akses terhadap sumberdaya (Prijono, A.M.W. Pranarka, 1996).

\section{Pemberdayaan Keluarga: Mengentas Kemiskinan}

Pemberdayaan masyarakat umumnya dilakukan untuk menanggulangi dan mengentas kemiskinan. Konsep pengentasan kemiskinan mencakup pemberian akses kepada kelompok miskin, pemberdayaan untuk bisa mandiri, peningkatan kapasitas, dan perlindungan sosial. Strategi perluasan akses merupakan faktor utama dalam pengentasan kemiskinan, karena warga miskin biasanya tidak memiliki kekuatan untuk membuka akses yang diperlukan. Membuka akses akan menciptakan masyarakat mendapatkan kesempatan dalam pemenuhan kebutuhan dasar dan peningkatan kesejahteraan secara berkelanjutan.

Pemerintah, dalam konteks ini, memiliki peran penting untuk membuka keterbatasan dan kebuntuan akses. Ketika kran akses dibuka lebar, maka masalah kemiskinan dapat direduksi bahkan diselesaikan. Penyelesaian masalah kemiskinan diakui dan diklaim telah dilakukan oleh pemerintah. Pemerintah mengklaim bahwa selain kemiskinan berhasil diturunkan, angka pengangguran pun telah turun. Klaim yang demikian tidak serta merta diterima dan diyakini oleh masyarakat. Sebagian besar masyarakat tidak sepenuhnya yakin terhadap angka pertumbuhan ekonomi (Utomo, 2015: 25). Pertumbuhan ekonomi harus dicapai dengan cara memperluas pemerataan (keadilan distribusi). Adil terjadi ketika hak seseorang mendapatkan porsi distribusi yang seimbang (Armour, 1994: 35). Kunci terpenting dalam pemerataan adalah bukan dengan proteksi ekonomi, melainkan dengan mengembangkan sistem proteksi sosial. Negara diniscayakan menciptakan lapangan kerja yang produktif dan pemerataan kesempatan usaha, agar setiap keluarga Indonesia memiliki pendapatan yang cukup untuk hidup berkelanjutan (Utomo, 2015: 25). 
Pendapatan yang cukup merupakan indikator bahwa kemiskinan telah berhasil dientas. Pengentasan kemiskinan akan lebih efektif melalui gerakan pemberdayaan keluarga. Sejak Peraturan Pemerintah nomor 21 tahun 1994 ditetapkan dan substansi peraturannya secara detail menempatkan keluarga sebagai pelaku pembangunan, maka ruh gerakan pemberdayaan sebenarnya mulai mewujud. Wujud gerakan semakin tampak jika keluarga memiliki dan menerapkan fungsi-fungsinya yang fundamental. Keluarga idealnya memiliki dan ditopang oleh delapan fungsi pokok, yaitu; agama, budaya, cinta kasih, perlindungan, reproduksi, sosial dan pendidikan, ekonomi, dan pemeliharaan lingkungan. Keluarga yang fungsional, modern, maju, profesional, berkualitas dan mandiri dapat memberdayakan masyarakat bahkan bangsanya (Suyono, t.th: 5). Gerakan di atas sekaligus menjadi strategi pemberdayaan masyarakat.

\section{Petani dan Pemberdayaannya}

Pemberdayaan petani adalah suatu upaya memposisikan petani sebagai pelaku dan penerima manfaat dari proses mencari solusi dan meraih hasil pertanian. Petani, karenanya, harus meningkatkan kualitas kemandiriannya dalam mengatasi masalah pertanian. Masalah yang dihadapi memang tidak mudah untuk diselesaikan melainkan harus ada upaya nyata. Peningkatkan kualitas petani terutama dalam membentuk dan merubah perilaku petani untuk mencapai taraf hidup yang lebih baik dan berkualitas adalah upaya konkret dalam pemberdayaan petani.

Ada beberapa strategi yang dapat ditempuh untuk membangun keberdayaan petani (Pambudy, Adhy, 2001: 68), di antaranya, adalah pertama, edukasi petani berawal dari tindakan mikro dan lokal. Edukasi petani yang dimulai dari tindakan mikro dan bersifat lokal memiliki jangkauan makro dan bersifat global. Strategi edukasi yang bernuansa mikro-makro menjadi elemen pembelajaran bagi petani agar berbagai pengalaman mikro dapat menjadi bahan pertimbangan sekaligus bahan kebijakan yang berdampak makro.

Strategi edukasi mikro-makro tidak disampaikan dengan pendekatan yang baku dan kaku melainkan disesuaikan dan inline 
dengan tuntutan dan kebutuhan petani lokal. Ketika kebutuhan dan tuntuan lokal adalah sasaran edukasinya, maka para penyuluh pun harus menyesuaikan diri dengan tuntutan dan kebutuhan mereka selama tidak menyimpang dari substansi edukasi mikro-makro, kedua, adaptasi pengembangan sektor ekonomi. Sektor ekonomi strategis dikembangkan sesuai dengan kondisi lokal karena setiap daerah memiliki potensi ekonomi yang berbeda. Kebijakan dan pemberlakuannya pun tidak sama antara satu daerah dengan daerah lain (Pambudy, Adhy, 2001: 57). Jadi, kebijakan yang berbeda juga diberlakukan secara berbeda sesuai dengan kondisi daerahnya.

Srategi lain yang juga penting dalam memberdayakan masyarakat petani adalah konstruksi kelembagaan masyarakat. Strategi yang ketiga ini adalah suatu strategi yang diciptakan oleh masyarakat karena munculnya kelembagaan sosial, ekonomi dan budaya yang diciptakan oleh masyarakat. Kehadiran lumbung desa merupakan salah satu contoh bangunan kelembagaan ekonomi masyarakat. Konstruk kelembagaan mungkin hanya menjadi bangunan monumental yang tidak bermakna dan tidak fungsional jika tidak didukung oleh kemampuan teknis pengelolanya. Karenanya, keberadaan strategi yang keempat merupakan suatu keniscayaan. Strategi yang keempat, pengembangan pengetahuan teknis sangat urgen dilakukan sesuai dengan desakan ilmu pengetahuan dan teknologi lokal. Ketergantungan masyarakat lokal pada input luar harus digeser bahkan disingkirkan dengan temuan inovatif lokal yang memiliki daya saing dengan produk inovatif luar. Temuan inovatif hanya dapat dikonstruk oleh masyarakat yang memiliki budaya saing. Daya saing masyarakat ditentukan oleh tingginya etos kerja masyarakat (Geertz, 1973: 126; Lindfelt, Tornroos, 2006: 332). Selain itu, penyuluhan yang bersifat sentralistik, top-down dan linier (Sumardjo, 1998) perlu diubah menjadi penyuluhan yang dialogissolutif yang mampu menyelesaikan masalah petani.

Masalah petani, bagaimana pun, tidak dapat dihadapi bahkan diselesaikanjika petanitidak memilikikesadaranuntuk menyelesaikan masalah tersebut. Membangun bahkan mengembangkan kesadaran petani selaku pelaku ekonomi adalah strategi yang kelima dalam pemberdayaan petani. Masalah ekonomi petani kerap terjadi karena ditimbulkan oleh politik ekonomi, sehingga tindakan yang hanya 
berorientasi memberikan bantuan teknis jelas tidak kuasa untuk memberdayakan masyarakat petani. Pemberdayaan yang berbasis kesadaran idealnya dapat membebaskan diri dari belenggu kekuatan ekonomi dan politik ekonomi.

Kran belenggu kekuatan ekonomi bisa dibuka selain oleh adanya kesadaran juga oleh adanya kekuatan jaringan. Jaringan sebagai strategi yang terakhir, keenam membuka peluang strategis untuk mengembangkan kerjasama dalam mengatasi keterbatasanketerbatasan kelompok petani baik dalam bidang produksi, pemasaran, teknologi dan permodalan. Kendala modal dapat diatasi oleh kekuatan kerjasama. Kerjasama dapat memangkas bahkan mengatasi hambatan modal, dan karenanya, kerjasama yang demikian kerap disebut dengan modal sosial. Modal sosial akan menjadi modal ekonomi.

\section{Metode Penelitian}

Penelitian yang dilakukan di wilayah Desa Luworo Madiun ini merupakan penelitian kualitatif. Penelitian kualitatif digunakan untuk memahami fenomena sosial-ekonomi, seperti fenomena ekonomi masyarakat petani di Desa Luworo, sehingga pendekatan yang tepat pun dalam penelitian ini adalah pendekatan Asset-Based Community Development (ABCD) (Wilke, 2006; Keeble, 2006: 1317; Wood, 2008: 11; Hicks, 2013: 11; Mathie, Cunningham, 2005: 176-177; D.L. Searcy, J.T. Mentzer, 2003: 130-167).

Pendekatan ABCD digunakan karena asset yang dimiliki oleh masyarakat baik berupa lumbung, masjid yang menjadi tempat bertemunya para petani, area masjid dan lumbung yang begitu luas, etos masyarakat, dan masyarakat petani yang guyub belum dikembangkan, bahkan bisa dikatakan "adanya" seperti "tidak ada". Pendekatan ABCD adalah sebuah pendekatan yang diharapkan dapat mengembangkan berbagai asset untuk mengatasi masalah ekonomi masyarakat petani yang sedang tersandera oleh kehadiran sistem ijon.

Pendekatan ini juga dipilih karena peneliti bukan hanya sebagai pihak yang menjaga jarak dengan masyarakat tetapi juga 
peneliti bersatu padu dan bersama-sama masyarakat menggali data berupa asset yang bisa dikembangkan. Asset yang melekat pada komunitas dan belum banyak terjamah oleh pengembangan perlu dipilah dan dikumpulkan, dan karenanya, metode yang digunakan dalam pendekatan ini mencakup observasi, interview, FGD, dan dokumentasi yang umumnya menggunakan kata tanya apa, mengapa, dan bagaimana. Berbagai kata tanya ini digunakan untuk mempertajam suatu kajian fenomena komunitas yang harus tunduk dan kembali kepada data bukan kepada pikiran.

Data yang diperoleh secara objektif ditulis dalam sebuah laporan melalui prosedur yang sistematis. Prosedur yang ditempuh peneliti adalah melakukan reduksi data (Moleong, 2006: 44; Miles, Huberman, 1994: 10; Sugiyono, 2005: 92), menyajikan data (Matthew B. Miles, A. Michael Huberman, 1994: 11), dan mengambil kesimpulan (S. Nasution, 1988: 128-130; Matthew B. Miles, Huberman, 1984: 21). Reduksi data dilakukan sebatas data yang mempunyai kesesuaian dengan permasalahan, penyajian dilakukan secara naratif, dan pengambilan kesimpulan dilakukan setelah semua data terkumpul, tetapi sifatnya masih tentatif, dan karena itu, data harus selalu diverifikasi selama penelitian berlangsung (Miles, Huberman, 1994: 11). Hasil verifikasi data yang dinarasikan dan dianalisis kemudian disimpulkan sebagai bagian dari temuan penelitian. Temuan tersebut dapat dipahami sebagai sesuatu yang orisinal jika dialektik dengan berbagai persoalan ekonomi dan solusi penguatan ekonomi masyarakat petani Desa Luworo Pilangkenceng Madiun.

\section{Analisis Hasil Penelitian}

\section{Ekonomi Masyarakat Petani Luworo}

Perekonomian masyarakat Muslim Luworo Madiun tergolong rendah. Tingkat perekonomian ini tentu mengundang kegelisahan yang terefleksi dari kesenjangan antara asset yang luas dengan ekonomi masyarakat yang rendah. Refleksi kegelisahan dalam format pertanyaan apakah asset lahan pertanian tidak digarap dengan baik; atau distribusi hasil panennya yang tidak tepat tidak dibiarkan mengalir tanpa respons. Berbagai kegelisahan yang demikian tentu 
harus direspons dengan benar untuk dapat memberikan solusi yang menjawab dan mengatasi kesenjangan di atas.

Persoalan yang pertama sebenarnya tidak terjadi dalam kehidupan petani. Para petani, dalam pandangan masyarakat Desa Luworo, telah mengolah lahan pertanian dengan baik dan penuh semangat. Perilaku dan aktifitas pertanian mereka dibenarkan oleh sebagian masyarakat yang sebenarnya tidak memiliki afinitas dengan bidang pertanian. Suwarno, salah seorang PNS yang peduli untuk mengatasi kemiskinan, membenarkan bahwa masyarakat petani Luworo memiliki semangat kerja yang baik (Wawancara, 17 Oktober 2015; Wawancara, 24 Oktober 2015).

Mereka bekerja tanpa kenal lelah. Indikator semangat kerja petani bisa diamati terutama ketika para petani terus bekerja, padahal saat itu hujan turun dan terus membasahi para petani (FGD, 10 Oktober 2015). Jika mereka bukan masyarakat yang memiliki etos kerja yang tinggi, maka mereka tentu segera meninggalkan pekerjaannya (Clifford Geertz, 1973: 126; Lise-Lotte Lindfelt, JanAke Tornroos, 2006: 332). Namun, kenyataannya mereka tetap bekerja bercocok tanam. Indikator lain yang juga menggambarkan pengelolaan lahan pertanian secara baik adalah tingginya tingkat kontribusi beras hasil panen masyarakat terhadap pasokan beras di Kabupaten Madiun (FGD, 10 Oktober 2015; BPS Kabupaten Madiun, 2015; http://madiunkab.go.id).

Jika memang demikian keadaannya, kemudian di mana letak permasalahannya? Persoalan yang kedua di atas, menurut Margono, tampak menjadi kendala dan bahkan membangun kesenjangan (Wawancara, 31 Oktober 2015; Wawancara, 24 Oktober 2015). Kesenjangan ditimbulkan oleh adanya mekanisme pasar yang tidak normal. Hasil panen pada umumnya tidak dapat didistribusikan secara leluasa oleh para petani malainkan diikat dan dibatasi oleh para tengkulak. Ikatan dan batasan cenderung manampilkan one side dan berpihak serta tergantung kepada pemodal bukan kepada petani. Ketergantungan petani pada input (modal) tengkulak jelas merefeksikan kuasa lebih.

Ikatan yang membelenggu kebebasan petani muncul dari adanya kuasa lebih dari para pemilik modal. Para petani pada 
umumnya mendapatkan modal dari tengkulak. Modal yang diberikan kepada para petani mengikat dan membatasi kebebasan para petani untuk menjual hasil panen secara normal. Para petani biasanya menjual--bahkan terpaksa menjual--hasil panennya kepada para tengkulak. Keterbatasan yang demikian menyebabkan keuntungan yang mereka peroleh juga bisa terbatas.

Keterbatasan keuntungan para petani jelas dapat mengkonstruk masalah ekonomi petani. Ekonomi masyarakat petani Luworo yang seharusnya mapan, namun karena keuntungan yang wajar bahkan keuntungan yang lebih hanya mengalir pada satu pihak, yakni tengkulak, dapat menciptakan kondisi ekonomi masyarakat petani Luworo terganggu bahkan melemah (FGD, 30 September 2015; Wawancara, 24 Oktober 2015). Lemahnya ekonomi masyarakat petani dan konstruksi kelemahan oleh pelemahan akses hasil panen tidak mungkin dapat diatasi jika sistem distribusinya pun tidak diperbaiki. Memperbaiki sistem distribusi hasil pertanian adalah suatu keniscayaan. Sistem distribusi hasil pertanian dipandang normal bila distribunya dilakukan melalui pasar yang normal.

Pasar dikatakan normal jika bekerjanya pasar berjalan normal tanpa dipengaruhi dan diintervensi oleh kekuatan lain. Pasar akan berjalan normal jika pasar tidak dipengaruhi oleh beberapa faktor, di antaranya, adalah mekanisme pasar yang tidak sehat. Pasar yang didesain dengan pola desain top-low ordinat cenderung membentuk transaksi yang terpaksa. Terpaksa melakukan transaksi karena ada kekuatan (top ordinat) dari salah satu pihak yang menghruskan orang lain (low ordinat) terlibat dalam suatu transaksi. Pola yang demikian tercermin, misalnya, dalam pola transaksi antara tengkulak dengan masyarakat petani Muslim Desa Luworo.

\section{Lumbung Hikmab: Konstruk Ketahanan Pangan}

Lumbung hikmah adalah sebuah lumbung yang kehadirannya di tengah-tengah masyarakat Ngudi Luhur Desa Luworo sangat penting dan berarti. Kehadiran lumbung digagas oleh pengurus dan jamaah masjid Ngudi Luhur untuk membangun ketahanan pangan dan sekaligus mengatasi problema ekonomi masyarakat petani Desa 
Luworo (Wawancara, 31 September 2015; FGD, 10 Oktober 2015). Ketahanan pangan dalam konteks kehidupan masyarakat petani Muslim Luworo dibangun karena ketika saat musim kemarau supply padi (beras) tidak berbanding lurus dengan kubutuhan (demand) konsumsi masyarakat. Jika antara supply dan demand tidak menyentuh titik keseimbangan, maka harga padi melambung tinggi yang kemudian berdampak pada tidak terjangkaunya masyarakat pentani untuk memenuhi kebutuhan konsumsi. Kehadiran lumbung hikmah, karenanya, merupakan suatu keniscayaan guna membangun ketahanan pangan.

Ketahanan pangan dapat diukur dengan indikator ketersediaan pangan dalam rumah tangga. Ukuran ketersediaan pangan dalam rumah tangga biasanya mengacu pada ketercukupan pangan dalam jumlah tertentu yang dapat memenuhi kebutuhan konsumsi rumah tangga. Batas waktu ketersediaan makanan pokok antara satu daerah dengan daerah lainnya dapat berbeda karena perbedaan jenis makanan pokok yang dikonsumsi. Karenanya, ukuran ketersediaan pangan merujuk pada dampak jenis makanan pokok yang dikonsumsi oleh masyarakat yang ukurannya dapat dipetakan sebagai berikut.

Rumah tangga yang makanan pokoknya adalah beras menggunakan cutting point 240 hari sebagai batas waktu untuk menentukan ketersediaan suatu rumah tangga apakah rumah tangga tersebut memiliki persediaan beras yang memadai atau tidak. Batas cutting point ini ditentukan dengan mempertimbangkan masa panen padi yang umumnya dilakukan sebanyak 2 kali atau 1 kali dalam setahun. Perbedaan rentang panen yang demikian tergantung pada perbedaan struktur lahan apakah termasuk lahan basah atau lahan kering, dan jika lahan kering, apakah ada pengairan buatan atau tidak (Wawancara, 7 Oktober 2015; FGD. 17 Oktober 2015).

Struktur lahan dan kecenderungan masyarakat Luworo dalam memperlakukan lahan partanian jelas dapat menentukan rentang panen jenis tanaman. Masyarakat Desa Luwowo, umumnya, mengolah lahan pertanian jenis tanaman padi dengan rentang panen 1 kali. Rentang panen ini bukan merupakan rentang panen yang baku dan monoton tetapi memungkinkan adanya jenis tanaman 
lain yang juga menjadi fokus olahan dan menjadi persedian pangan masyarakat Luworo. Tanaman ketela, selain tanaman jagung, adalah jenis tanaman lain yang juga menjadi agenda tahunan masyarakat petani Luworo (Wawancara, 31 Oktober 2015; Wawancara, 24 Oktober 2015).

Tanaman ketela dijadikan agenda tahunan dan teragendakan di sela-sela masa panen padi untuk menopang dan membangun ketahanan pangan masyarakat petani Loworo (Wawancara, 31 Oktober 2015). Ketela, sekalipun bukan makanan pokok, menjadi makanan substitusi untuk menyangga makanan pokok terutama pada musim paceklik. Ketela kering yang kerap disebut oleh masyarakat Jawa dengan sebutan gaplek adalah bahan dasar pembuatan tiwul sebagai pengganti makanan pokok nasi. Ketersediaan makanan, baik makanan pokok maupun makanan substitusi, memang menunjukan stabilitas ktersediaan pangan.

Stabilitas ketersediaan pangan dalam rumah tangga diukur berdasarkan kecukupan ketersediaan makanan dan frekuensi makan anggota rumah tangga dalam sehari. Satu rumah tangga dikatakan stabil karena memiliki ketersediaan pangan yang juga stabil. Ketersediaan pangan rumah tangga dikatakan stabil jika mereka memiliki persediaan makanan pokok di atas cutting point 240 hari dan anggota rumah tangga dapat makan tiga kali sehari sesuai dengan kebiasaan makan penduduk desa tersebut. Dalam satu rumah tangga, salah satu cara untuk mempertahankan ketersediaan pangan dalam jangka waktu tertentu adalah dengan mengurangi frekuensi makan atau mengkombinasikan bahan makanan pokok, beras, dengan makanan substitusi, tiwul (FGD, 10 Oktober 2015).

Frekuensi makan sebanyak tiga kali adalah indikator kecukupan makan yang didasarkan pada kondisi nyata masyarakat Desa Luworo. Masyarakat Luworo yang memiliki persediaan makanan pokok "cukup" pada umumnya makan sebanyak tiga kali sehari. Jika mayoritas rumah tangga di Desa Luworo, misalnya, hanya makan dua kali setiap hari, maka kondisi yang demikian hanya merupakan strategi rumah tangga untuk mengatur ketercukupan persediaan makanan pokok mereka agar tidak cepat habis. Sebaliknya, jika di saat persediaan pangan menipis, 
dan rumah tangga masyarakat Loworo tidak mengurangi frekuensi makannya, maka kebanyakan rumah tangga masyarakat teresbut tidak bisa bertahan untuk tetap memiliki persediaan makanan pokok hingga panen berikutnya. Dalam kondisi inilah, kehadiran pembiasaan kombinasi makanan--makanan pokok dan makanan sustitusi--merupakan suatu keharusan.

Kombinasi antara ketersediaan makanan pokok dan makanan substitusi dengan frekuensi makan kategori yang tiga kali per hari disebut cukup makan, dua kali disebut kurang makan, dan satu kali disebut sangat kurang makan merupakan kombinasi yang menjadi indikator kecukupan pangan sebagaimana indikator stabilitas ketersediaan pangan dalam tabel dibawah ini.

\section{Tabel 1}

\section{Ukuran Ketersediaan Pangan}

\begin{tabular}{lccc}
\hline $\begin{array}{c}\text { Kecukupan ketersediaan } \\
\text { pangan }\end{array}$ & \multicolumn{2}{c}{ Frekuensi makan anggota rumah tangga } \\
\hline & $\mathbf{3}$ kali & 2 kali & $\mathbf{1 ~ k a l i}$ \\
$\begin{array}{l}\text { 240 hari (beras) }>360 \text { hari } \\
\text { (jagung) }\end{array}$ & Stabil & Kurang stabil & Tidak stabil \\
$\begin{array}{l}\text { 1-239 hari (beras) } 1-364 \\
\text { hari (jagung) }\end{array}$ & Kurang stabil & Tidak stabil & Tidak stabil \\
Tidak ada persediaan & Tidak stabil & Tidak stabil & Tidak stabil \\
\hline
\end{tabular}

Sumber: (Pusat Penelitian Kependudukan LIPI, 2013).

Dari tabel di atas, dapat dipahami bahwa masyarakat petani Luworo yang frekuensi makannya sebanyak tiga kali dikatakan sebagai masyarakat yang memiliki ketersediaan pangan stabil, sementara masyarakat yang frekuensi makannya dua atau satu kali adalah gambaran masyarakat yang memiliki ketersediaan pangan kurang stabil atau tidak stabil. Menurut Sri Hartatik, Seger, dan Loso, sewaktu Paceklik makannya masyarakat petani Desa Luworo hanya satu atau dua kali sehari. Masyarakat tidak memiliki kemampuan untuk memenuhi kebutuhan makan sebanyak tiga kali (Wawancara, 7 Oktober 2015; FGD, 10 Oktober 2015). Pengakuan masyarakat yang demikian menunjukkan gambaran riil ketersediaan pangan masyarakat yang kurang stabil. 
Gambaran ketersediaan pangan masyarakat petani Desa Luworo yang kurang stabil, bahkan tidak stabil, merupakan gambaran persoalan ekonomi yang harus disikapi terutama oleh masyarakat setempat. Sikap masyakarat Desa Luworo, melalui lumbung masjid, adalah suatu sikap kepedulian mereka untuk membangun ketahanan pangan dan sekaligus mengatasi masalah ekonomi masyarakat Luworo yang relatif kurang mampu dan kurang berdaya. Sikap kepedulian yang demikian tentu masih menyisakan pertanyaan penting. Pertanyaannya adalah bagaimana sikap masyarakat dalam upaya membentuk ketahanan pangan? Jawaban atas pertanyaan ini sebenarnya telah tergambar dalam bahasan awal bab ini yang mengawali tentang kehadiran lumbung masjid. Namun, pada bagian ini tidak diungkap tentang bagaimana masyarakat petani Desa Luworo membangun lumbung masjid di tengah-tengah perekonomian berbasis ijon. Persoalan ekonomi berbasis ijon-seperti yang dijelaskan bagian terdahulu--telah mendorong warga masyarakat petani Desa Luworo untuk membangun lumbung masjid.

Lumbung masjid dibangun untuk mengembangkan ekonomi mandiri masyarakat berbasis syariah. Misi yang cukup singkat tetapi padat makna memiliki beberapa tujuan pokok. Tujuan yang utama dan mendasar adalah meningkatkan ekonomi masyarakat petani dan mereduksi bahkan menghilangkan sistem hutang piutang dengan bunga tinggi. Mereduksi bahkan meniadakan sistem bunga bukan hal yang mudah tetapi membutuhkan strategi yang baik. Lumbung masjid yang terdiri dari dua kata lumbung dan masjid merefleksikan nilai yang saling mengikat dan menjadi salah satu strategi untuk mendekatkan sistem ekonomi yang islami kepada masyarakat petani (Ife, Tesoriero, 2008: 447-448). Lumbung yang orientasi usahanya pada penguatan pangan dan masjid yang berfungsi dan memiliki misi untuk menjaga moral jamaah adalah dua kata yang jika keberadaan satu dengan yang lain menjadi unsur senyawa dapat memperkuat ekonomi masyarakat tanpa terjebak pada praktik ekonomi ijon.

Menyatukan unsur ekonomi dengan nilai keislaman melalui nilai filosofis kata lumbung dan masjid tentu merupakan motivasi kuat dalam pendirian lumbung masjid. Karenanya, masyarakat petani Desa Luworo membangun sebuah lumbung masjid Lumbung 
Hikmah Ngudi Luhur di saat ekonomi masyarakat petani berada pada situasi terpuruk. Salah satu indikator terpuruknya ekonomi masyarakat adalah ketersediaan pangan mereka yang kurang stabil, bahkan tidak stabil, terutama pada musim kemarau yang kerap dikenal dengan musim paceklik. Kehadiran lumbung hikmah diniscayakan selain untuk membangun ketahanan pangan sebagaimana yang diuraikan di atas juga untuk memperkuat ekonomi masyarakat. Penguatan ekonomi masyarakat melalui program lumbung hikmah dapat dijelaskan secara detail pada tema berikut.

\section{Lumbung dan Penguatan Ekonomi Masyarakat}

Lumbung, dalam konteks ini lumbung hikmah, dan penguatan ekonomi adalah dua istilah variabel yang menjadi fokus kajian dalam tema ini. Dua variabel penting ditempatkan pada awal pembahasan sebagai kunci dasar untuk membuka dan menyoroti kehadiran lumbung, apakah lumbung hikmah benar-benar merupakan sebuah asset ekonomi yang telah atau justeru belum dapat mengatasi masalah ekonomi masyarakat. Jika memang belum, maka di sinilah urgensi pendampingan berbasi riset untuk mendukung dan mendevelope lumbung sebagai asset ekonomi masyarakat. Lumbung hikmah, atau yang lebih dikenal dengan sebutan lumbung masjid, secara nyata memang belum beroperasi laiknya lumbung karena terkendala modal operasional.

Modal operasional yang menjadi kendala dapat diatasi dengan adanya kesadaran petani yang mulai terlibat dalam keanggotaan lumbung. Setiap anggota menyediakan padi sebanyak $50 \mathrm{~kg}$. Keterlibatan masyarakat petani, sebagai refleksi dari semangat kerjasama, dalam keanggotaan lumbung tentu dapat mengatasi kendala permodalan awal dan sekaligus mendukung kehadiran lumbung. Kehadirannya sebagai asset ekonomi adalah untuk membangun ketahanan pangan dan kekuatan ekonomi masyarakat (FGD, 10 Oktober 2015; FGD, 17 Oktober 2015). Asset lumbung tidak mungkin dapat hidup bahkan berkembang jika tidak didukung oleh asset-asset lainnya. Masjid, pasar, area pertanian, dan masyarakat adalah asset-asset lain yang keberadaannya sangat penting untuk mengkostruk survivalitas dan pengembangan asset lumbung yang secara sistemik tergambar dalam gambar berikut. 


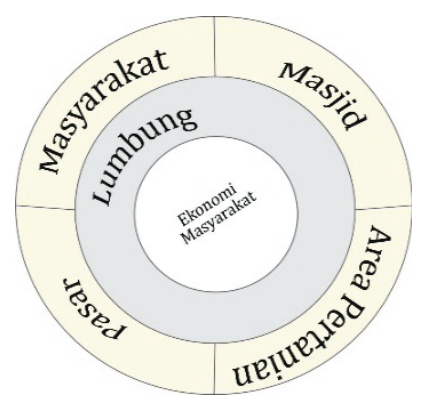

\section{Gambar 1 \\ Sistem Asset}

Gambar di atas menunjukkan sebuah sistem asset yang mendukung penguatan lumbung dan ekonomi masyarakat. Asset masjid yang memiliki multi fungsi, asset pasar sebagai tempat bertemunya transaksi ekonomi, asset area lahan pertanian yang menjadi lahan ekonomi, dan asset masyarakat baik sebagai pelaku ekonomi maupun sebagai pendukung adalah asset-asset yang saling terkait dan tidak dapat dipisahkan untuk menyangga keberadaan lumbung. Keberadaan lumbung akan memiliki kekuatan bukan sekadar kekuatan membangun ketahanan pangan tetapi juga kekuatan ekonomi masyarakat.

Kekuatan ekonomi masyarakat adalah kekuatan ekonomi yang hendaknya dibangun melalui fleksibilitas lumbung dalam mengcreat variasi program lumbung dan bukan program yang monoton simpan dan pinjam. Program yang variatif memang cenderung berisiko tinggi terutama jika segala perangkat pengendalinya tidak mendukung. Salah satu kendali yang membatasi gerak liar lumbung adalah adanya legal formal yang mengikat dan memberikan kepastian hukum jika terjadi risiko (FGD, 10 Oktober 2015; FGD, 17 Oktober 2015).

Lumbung masjid yang legal yang dibangun dari dan untuk anggota memiliki mekanisme kerja yang diatur atas kesepakaan bersama dalam rapat anggota. Keanggotaan lumbung masjid mencakup seluruh jamaah masjid dan musala yang berada di Dukuh Peron Desa Luworo Kecamatan Pilangkenceng Kabupaten Madiun. Jamaah masjid yang bergabung dalam keanggotaan lumbung adalah jamaah Masjid Baitussalam, Masjid Al-Hidayah, Musala RT.12, Musala RT.13, dan Musala RT.16 yang telah mendaftarkan diri dan bersedia menjadi anggota lumbung masjid (FGD, 10 Oktober 2015). 
Keanggotan jamaah masjid dan musala sebagai anggota lumbung masjid dipetakan menjadi berberapa jenis keanggotaan, yaitu; pertama, anggota umum, adalah anggota lumbung yang telah membayar simpanan wajib gabah dan memiliki hak meminjam, kedua, anggota khusus, yaitu anggota lumbung yang telah membayar simpanan wajib gabah tetapi tidak meminta hak meminjam dan hanya sebagai donator, ketiga, anggota luar biasa, yakni anggota lumbung yang tidak mampu membayar simpanan wajib gabah tetapi mempunyai hak meminjam, dan keempat, anggota sangat luar biasa, adalah anggota masyarakat umum yang belum menjalankan syariat Islam yang tidak mampu membayar simpanan wajib gabah tetapi mempunyai hak meminjam dengan mengatasnamakan hak anggota umum dan menjadi tanggung jawab anggota umum tersebut (Wawancara, 7 Oktober 2015; FGD, 10 Oktober 2015).

Keanggotaan dan tata kerja lumbung merupakan elemen senyawa yang harus saling mengikat satu dengan lainnya. Jumlah anggota yang banyak belum tentu dapat menciptakan kesuksesan lumbung yang sekaligus kesuksesan anggotanya jika anggota tidak memahami dan mengikuti tata kerja baku yang menjadi platform pengelolaan lumbung, dan sebaliknya, tata kelola lumbung yang bagus juga belum dapat menjamin kesuksesan lumbung jika tidak didukung oleh anggota yang memadai sebagai kontributor gabah lumbung. Oleh karenanya, keanggotaan dan mekanisme kerja lumbung adalah dua hal penting untuk membangun keberdayaan lumbung.

Mekanisme kerja lumbung memuat beberapa diktum yang mengikat. Anggota umum dan anggota khusus membayar simpanan wajib gabah di masa panen sebanyak $50 \mathrm{~kg}$ minimal satu tahun sekali. Anggota umum bisa merubah dirinya menjadi anggota khusus atau sebaliknya sesuai perrmintaan dan keadaan ekonomi anggota. Anggota umum dan anggota khusus diperbolehkan membayar gabah sebanyak-banyaknya setiap panen selama satu tahun sesuai dengan kemampuan anggota. Gabah simpanan wajib maupun gabah anggota yang dibayarkan dengan sukarela bukan menjadi hak milik lumbung tetapi tetap menjadi hak anggota sesuai jumlah yang dibayarkan kecuali dihibahkan dengan tujuan ibadah (FGD, 17 Oktober 2015; Wawancara, 17 Oktober 2015; Wawancara, 24 Oktober 2015). 
Gabah yang berada di lumbung masjid dan menjadi milik anggota dapat ditarik dan diambil kembali oleh anggota dan menjadi hak pribadinya sebanyak gabah yang dibayarkan dengan mekanisme penarikan secara bertahap melalui musyawarah anggota. Gabah yang berada di lumbung masjid didistribusikan kepada anggota umum, anggota luar biasa, dan anggota sangat luar biasa sebanyak satu kali selama satu tahun dan seluruh gabah tersebut dihabiskan pada musim paceklik. Gabah yang telah didistribuskan harus dikembalikan kepada lumbung pada saat panen raya dengan asumsi jumlah dalam kilogram dan bukan asumsi harga dalam rugpiah. Gabah yang diberikan kepada peminjam jumlahnya dipotong 10\% sebagai biaya administrasi dan kas lumbung yang tidak merugikan peminjam (Wawancara, 17 Oktober 2015; Wawancara, 24 Oktober 2015). Pemotongan 10\% dipandang tidak merugikan peminjam karena adanya asumsi bahwa harga gabah yang tinggi pada masa paceklik dan harga gabah yang relatif murah pada saat panen raya.

Pemotongan 10\% dari jumlah gabah yang dipinjam dari lumbung, bagaimanapun, masih menuai pro dan kontra. Ada yang mengatakan boleh dan ada yang mengatakan tidak boleh. Kelompok pandangan yang mengatakan boleh adalah karena besaran jumlah pemotongan menjadi keuntungan lumbung dan akan kembali kepada semua anggota. Sebesar apapun potongannya tetap kembali kepada semua anggota, termasuk anggota yang meminjam. Selain itu, dasar pemotongannya pun adalah biaya administrasi, dan selesih harga. Selisih harga antara tahun pinjam dan tahun kembali mencerminkan harga kemplementatif yang tidak merugikan siapapun baik pihak peminjam dan pihak lumbung. Sedangkan kelompok yang kontra beranggapan bahwa pemotongan yang demikian tidak berbeda dengan bunga. Prosentasi yang pasti dari modal pinjaman dan bukan dari keuntungan usaha lumbung adalah tidak dibenarkan dalam Islam.

Pandangan kelompok yang kedua sebenarnya merupakan pandangan yang sangat hati-hati agar tidak terjebak dalam kontrak yang bertentangan dengan Islam. Ketika lumbung dikonstruk dan dasar konstruksinya adalah berbasis kemasjidan, maka tentu sikap hati-hati patut diapresiasi untuk tetap menjaga nilai-nilai syariah dalam pengelolaan lumbung. Pandangan yang berbeda di atas terlihat saat 
diskusi dalam acara FGD (10 Oktober 2015; 17 Oktober 2015). FGD dilakukan untuk menampung dan membahas berbagai persoalan, termasuk persoalan yang mempertanyakan kesyariahan lumbung. Wajar jika pandangan yang berbeda muncul untuk menciptatakan kondisi ideal yang berpihak kepada semua pihak dan bukan berpihak kepada salah satu pihak. Keberpihakan kepada salah satu pihak bukan merupakan karakter genuine lumbung yang berbasis syariah karena mengkonstruks ketidakadilan. Ketidakadilan adalah suatu entitas yang harus dihindari untuk menciptakan keuntungan yang menjadi hak baik lumbung maupun seluruh anggota. Hak lumbung dan hak anggota hendaknya mencerminkan hak yang sama sebagai bentuk keadilan.

Keadilan yang menjadi ruh lumbung berusaha memotong mata rantai kezaliman yang terjadi dalam transaksi ijon. Sistem ijon tidak memberikan peluang yang sama kepada semua pihak malainkan hanya berpihak kepada tengkulak. Kebebasan petani diikat oleh kekuasaan tengkulak yang memberikan modal pertanian. Ketika kebebasan petani terkungkung dan petani harus menjual hasil panennya kepada tengkulak, maka harga pun tergantung pada kuasa tengkulak. Di sinilah distorsi keuntungan terjadi dan keberpihakan hanya melekat pada diri tengkulak. Keberpihakan yang demikian tentu merefleksikan mekanisme pasar yang tidak berjalan dengan normal. Pasar sebagai asset ekonomi menjadi media yang mempertemukan dua kepentingan antara penjual dengan pembeli. Pedagang selaku pembeli dan petani selaku penjual memiliki hak yang sama untuk mendapatkan keuntungan.

Hak yang sama dan bukan hak yang mencerminkan top-sub ordinat membutuhkan pasar yang bebas namun terbatas oleh nilainilai keislaman. Pasar memiliki kebebasan baik dalam menentukan cara produksi maupun dalam menentukan harga. Namun dalam kenyataannya sulit ditemukan pasar yang berjalan secara adil (fair) seperti yang tergambar dalam ekonomi ijon. Distorsi pasar sering terjadi sehingga dapat merugikan para pihak. Pasar yang dibiarkan berjalan sendiri, tanpa ada yang mengontrol, menyebabkan penguasaan pasar sepihak oleh pemilik modal. Lumbung masjid, dalam kaitan ini, berupaya mengontrol dan memastikan kompetisi di pasar berlangsung dengan sempurna, sehingga dapat menciptakan 
keadilan ekonomi yang sekaligus juga memberdayakan ekonomi masyarakat petani Muslim Luworo Madiun.

\section{Kesimpulan}

Masyarakat petani Muslim Luworo Madiun membangun lumbung masjid untuk menciptakan ketahanan pangan dan mengatasi problem ekonomi masyarakat.. Lumbung masjid yang memuat kata lumbung dan masjid merefleksikan nilai yang senyawa sekalipun orientasinya berbeda. Lumbung yang orientasi usahanya pada penguatan pangan dan masjid yang berfungsi dan memiliki misi menjaga moral jamaah adalah dua variabel yang saling mengikat untuk memperkuat ekonomi masyarakat tanpa terjebak pada praktik ekonomi ijon.

Menyatukan unsur ekonomi dengan nilai keislaman melalui nilai filosofis kata lumbung dan masjid tentu merupakan motivasi kuat dalam pendirian lumbung masjid. Karenanya, masyarakat petani Muslim Desa Luworo membangun sebuah lumbung masjid di saat ekonomi masyarakat petani berada pada situasi terpuruk. Salah satu indikator terpuruknya ekonomi masyarakat adalah ketersediaan pangan mereka yang kurang stabil, bahkan tidak stabil, terutama pada musim paceklik. Kehadiran lumbung masjid selain untuk membangun ketahanan pangan juga untuk memperkuat ekonomi masyarakat.

Lumbung masjid yang belum beroperasi laiknya lumbung memang terkendala modal operasional. Adanya modal pun tidak serta-merta membuat asset lumbung dapat hidup apalagi berkembang. Asset lumbung tidak mungkin dapat hidup bahkan berkembang jika tidak didukung oleh asset-asset lainnya. Keberadaan asset masjid, pasar, area pertanian, dan masyarakat adalah assetasset yang dikembangkan oleh masyarakat petani Muslim Desa Luworo untuk mengkostruk survivalitas dan pengembangan asset lumbung. Keberadaan lumbung memiliki kekuatan bukan sekadar kekuatan membangun ketahanan pangan tetapi juga kekuatan ekonomi masyarakat. Kekuatan ekonomi masyarakat terbentuk melalui kebijakan lumbung yang memberikan hak yang sama 
secara adil kepada semua anggota dan bukan kezaliman seperti yang terkonstruk dalam sistem ekonomi ijon.

\section{Daftar Pustaka}

Arif, Rahmat, et al. 2015. Upaya Peningkatan Ekonomi Masyarakat melalui Pendirian Pasar Lokal di Desa Luworo Kecamatan Pilangkenceng Kabupaten Madiun. Laporan Penelitian-UIN Sunan Ampel, Surabaya.

Asmara, Rosihan, Hanani, Nuhfil, dan Suryaningtyas, Risma. 2011. Analisis Usaha Tani Manggis dan Faktor-faktor Sosial Ekonomi yang Mempengaruhi Keputusan Petani Memasarkan Hasil Usaha Tani Manggis dengan Sistem Ijon. Agrise, Vol. 11, No. 2: 129-130.

Armour, Leslie. 1994. Is Economic Justice Possible? International Journal of Social Economics, Vol. 21, Nos. 10/11/12: 32-58.

BPS Kabupaten Madiun. 2015.

Fikriyah, Luluk. Wawancara. Surabaya, 22 September 2015, pukul 13.15-13.40 WIB.

Geertz, Clifford. 1973. Ethos, World View and the Analysis of Sacred Symbol, dalam Clifford Geertz, The Interpretation of Cultures (Kumpulan Artikel).

Hartatik, Sri dan Loso. Wawancara. Luworo, 24 Oktober 2015, pukul 13.15-15.40 WIB.

Hartatik, Sri, Loso, Sukadi, dan Suwarno. Focus Group Discussion. Luworo, 10 Oktober 2015, pukul 13.00 WIB-16.25 WIB.

Hartatik, Sri, Seger, dan Loso. Wawancara. Luworo, 7 Oktober 2015, pukul 16.00-16.45 WIB. 
Hartatik, Sri, Suwarno dan Loso. Focus Group Discussion. Luworo, 17 Oktober 2015, pukul 13.00-16.30 WIB.

Hasyim, Muh. Fathoni dan Jamali. Wawancara. Surabaya, 18 September 2015, pukul 14.30-15.05 WIB.

Hicks, Rachel Marie. 2013. Asset-Based Citizen Development: A Theorethical Contribution. Thesis, MA-The University of Alabama.

http://madiunkab.go.id (Diakses pada 21 Nopember 2015).

Ife, Jim and Tesoriero, Frank. 2008. Community Development: Alternatif Pengembangan Masyarakat di Era Globalisasi, terj. Sastrawan Maang. Yogyakarta: Pustaka Pelajar.

Keeble, Sarah. 2006. Asset-Based Community Development: A Literature Review. Humboldt State: Humboldt State University Department of Sociology Senior Project.

Kepala Desa Luworo. 2015. Data Penduduk Desa Luworo Kecamatan Pilangkenceng Kabupaten Madiun tahun 2015. Madiun: Desa Luworo.

-----. 2015. Data Profil Desa Luworo Kecamatan Pilangkenceng Kabupaten Madiun tahun 2015. Madiun: Desa Luworo.

Lindfelt, Lise-Lotte and Tornroos, Jan-Ake. 2006. Ethics and Value Creation in Business Research: Comparing Two Approaches, European Journal of Marketing, Vol. 40, No. 3/4: 332 .

Mardikanto, Totok. 2014. Pemberdayaan Masyarakat oleh Perusahaan. Yogyakarta: UNS Press.

Margono dan Suwarno. Focus Group Discussion, Luworo, 10 Oktober 2015. 
Margono, Hartatik, Sri, Seger, dan Loso. Focus Group Discussion. Luworo, 17 Oktober 2015, pukul 13.30 WIB-17.30 WIB.

Margono, Jaiman, Hartatik, Sri dan Seger. Focus Group Discussion. Luworo, 17 Oktober 2015, pukul 13.30 WIB-17.30 WIB.

Margono. Wawancara. Luworo, 3 Oktober 2015, pukul 13.4015.25 WIB.

-----. Wawancara. Luworo, 30 September 2015, pukul 13.25 WIB. -15.00 WIB.

------. Wawancara. Luworo, 31 Oktober 2015, pukul 14.19-17.45 WIB.

------. Wawancara. Luworo. 24 Oktober 2015, pukul 16.15-16.40 WIB.

-----. Wawancara. Luworo, 31 September 2015, pukul 13.0014.45 WIB.

Mas'oed, Mohtar. 1990. Ilmu Hubungan Internasional: Disiplin dan Metodologi. Jakarta: Pustaka LP3S.

Mathie, Alison and Cunningham, Gord. 2005. Who is Driving Development? Reflection on the Transformative Potential of Asset-Based Community Development. Canadian Journal of Development Studies, Vol. 26, No. 1: 176-177.

Miles, Matthew B. and Huberman, A. Michael. 1994. Qualitative Data Analysis: an Expanded Sourcebook. London: Sage Publications.

Pambudy dan Adhy, A.K. 2001. Pemberdayaan Sumber Daya Manusia Menuju Terwujudnya Masyarakat Madani. Bogor: Pustaka Wirausaha Muda. 
Prijono, Onny S. dan Pranarka, A.M.W. 1996. Pemberdayaan: Konsep, Kebijakan, dan Implementasi. Jakarta: Centre for Strategic and International Studies.

Pusat Penelitian Kependudukan LIPI. 2013. Ukuran Ketersediaan Pangan. Jakarta: LIPI.

Sukadi, Pasri, Samiran. Wawancara. Luworo, 31 Oktober 2015, pukul 12.45-15.20 WIB.

Sumodinigrat, Gunawan. 1999. Pemberdayaan Masyarakat dan Jaring Pengaman Sosial. Jakarta: PT. Gramedia Pustaka Utama.

Sunaryo. Wawancara. Luworo, 7 Oktober 2015, pukul 07.47 WIB.

------. Focus Group Discussion. Luworo, 30 September 2015, pukul 13.25 WIB. -15.00 WIB.

------. Wawancara. Luworo, 17 Oktober 2015, pukul 16.35-17.00 WIB.

Suwarno dan Loso. Focus Group Discussion, Luworo. 10 Oktober 2015, pukul. 13.30-16.30 WIB.

Suyono, Haryono. Memotong Kemiskinan. Jakarta: Yayasan Dana Sejahtera Mandiri, t.th.

------ 2015. Panduan Pemberdayaan Keluarga Sejahtera melalui Posdaya dalam Ranngka Penanggulangan Kemiskinan. Jakarta: Yayasan Damandiri.

Utomo, Dwidjo. 2015. Posdaya Disabilitas. Jakarta: Yayasan Damandiri.

Wijaya M., Faried. 1991. Perkreditan \& Bank dan Lembaga-lembaga Keuangan Kita. Yogyakarta: BPFE. 
Wilke, Julie. 2006. Understanding the Asset-Based Approach to Community Development. CRP Participatory Methods, 2/9/06.

Wood, Suzanne Killing. 2008. Asset-Based Community Development: A Case Study. Thesis, MA-Wilfrid Laurier University. 